\title{
RESPONSE OF HOARY ALYSSUM (Berteroa incana L.) TO UV-B RADIATION
}

\section{${ }^{1}$ Agnieszka Stokłosa, ${ }^{2}$ Hamid Madani, ${ }^{3}$ Mahesh K. Upadhyaya}

\author{
${ }^{1}$ Department of Agrotechnology and Agricultural Ecology, University of Agriculture, \\ Al. Mickiewicza 21 31-120 Kraków, Poland. \\ ${ }^{2}$ Department of Agronomy, Arak Branch, Islamic Azad University, Arak, Iran, P.O.Box.38135/567 \\ ${ }^{3}$ Faculty of Land and Food Systems, University of British Columbia, Vancouver V6T 1Z4, Canada \\ e-mail: a.stoklosa@ur.krakow.pl
}

Received: 10.01.2012

\begin{abstract}
This greenhouse experiment evaluated the response of hoary alyssum plants, up to the rosette phase, to different levels of UV-B radiation. The experiment was carried out in the chambers, equipped with UV-B lamps, emitting biologically effective UV-B radiation of 0 (control), 4, 6 or $8 \mathrm{~kJ}$. As a result, specific traits of the plants such as: leaf number, lamina length, leaf area, specific leaf weight, relative chlorophyll content and shoot biomass were unaffected by any of the UV-B treatments. Significant reductions in the share of large leaves, leaf stalk length and root biomass were noted for plants growing under 8 kJ UV-B ${ }_{\mathrm{BE}}$.
\end{abstract}

Key words: Berteroa incana L., UV-B stress, morphological traits, leaf rosette phase

\section{INTRODUCTION}

Hoary alyssum (Berteroa incana L.), from the mustard family is a species found in segetal or ruderal communities (Kutyna and $\mathrm{Nieczkowska}$, 2009; Skrzyczyńska et al. 2010), on pastures (Warwick and Francis, 2006), and is also regarded as an invasive species in North America (P a r k in s o n et al. 2010). Hoary alyssum adapts well to different climate conditions and for this reason is a successful invader both in temperate and continental climates (P a r k i n s o n et al. 2010). This is an annual or short-perennial plant of very high seed production (R e i c h m a n n, 1988), which can germinate in temperatures as high as $40^{\circ} \mathrm{C}$ ( $\mathrm{M}$ a d a n i et al. 2010).

During growth, hoary alyssum is exposed to high solar radiation and also high UV-B levels. The same species show different tolerance to UV-B depen- ding on the environmental conditions in which they are growing (Frohn me yer and S ta i ger, 2003), which may influence the competitive relationships. The experiment of Furness et al. (1999) demonstrates that weeds of horizontal leaf orientation are more susceptible to UV-B radiation, which may be a very positive phenomenon in the conditions of grasses vs. dicotyledonous weeds competition in grasslands, where hoary alyssum is a strong competitor against valuable pasture species (G a y t o n, 2004). The relevant scientific literature lacks any information on the influence of UV-B radiation on growth and development of hoary alyssum, which could explain its competitive potential against grasses in the presence of a stress factor such as enhanced UV-B radiation levels. In order to address this gap in the literature, our experiment sought to assess the influence of UV-B radiation on hoary alyssum vegetative growth (up to the rosette phase of development).

\section{MATERIAL AND METHODS}

A pot experiment was carried out in the greenhouse of the Faculty of Land and Food Systems at the University of British Columbia in 2010. Seeds of a rangeland weed species - hoary alyssum (Berteroa incana (L.) Dc.) - were collected in July 2008. Pre-germinated seeds were transferred into pots $(9.0 \times 9.0 \times$ $10.0 \mathrm{~cm})$ filled up with a top layer of soil $(66.1 \%$ sand; $24.9 \%$ silt; $9.0 \%$ clay; $8.4 \%$ organic matter; $4.14 \%$ C; $0.24 \% \mathrm{~N} ; 115.8 \mathrm{ppm} \mathrm{P}_{2} \mathrm{O}_{4} ; \mathrm{pH}$ 5.90). The pots were placed under the UV-B treatments (chambers) and the plants were allowed to grow for 13 weeks. UV-B treatments were provided by UVB-313 40W fluorescent 
tubes, installed $1.10 \mathrm{~m}$ above the greenhouse bench, in 4 chambers $1.20 \mathrm{~m}$ long $\times 1.20 \mathrm{~m}$ wide $\times 1.25 \mathrm{~m}$ high . In each chamber 10 fluorescent tubes were placed. The chambers were enclosed on all four sides with Mylar film (Type D, $0.127 \mathrm{~mm}$ thick). Within each chamber, small wooden frames $(60.0 \mathrm{~cm} \times 32.0 \mathrm{~cm} \times 40.0 \mathrm{~cm}$ high) were placed. The frames were covered on top and on the sides with either a layer of Mylar film, or one, two or three layers of cellulose acetate film (diacetate type, $0.127 \mathrm{~mm}$ ). Mylar film absorbs all UV-radiation below $320 \mathrm{~nm}$ and cellulose acetate below 290 $\mathrm{nm}$ (B arnes et al. 1988). Several cellulose acetate layers provided the different levels of UV-B radiation, whereas the Mylar treatment was employed to simulate the ambient greenhouse conditions.

UV-B radiation (290-320 $\mathrm{nm}$ ) was measured in single nanometer increments using an International Light IL1700 Radiometer interfaced with an IL782A double-slit monochromator. Biologically effective UV-B $\left(\mathrm{UV}-\mathrm{B}_{\mathrm{BE}}\right.$ ) radiation was estimated from these readings using C a ldwell's (1971) generalized plant damage action spectrum normalized to $300 \mathrm{~nm}$. Daily UV-B exposure for 8 hours, centered on solar noon, provided

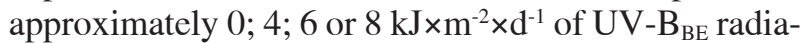
tion in the frames covered either with a layer of Mylar film, or three, two, or one layer(s) of cellulose acetate film, respectively.

The hoary alyssum plants in the rosette phase were taken for the measurements, which included: the relative chlorophyll content, using a Minolta SPAD 502 Meter, and morphological features, namely number of leaves, length of petiole and lamina along with leaf area. Roots and rosettes were dried separately in a drier at $50^{\circ} \mathrm{C}$ for $72 \mathrm{~h}$ and weighed.

Based on lamina dry matter and area, the specific leaf weight (SLW) value was calculated according to the following formula: lamina dry matter $(\mathrm{g}) /$ lamina area $\left(\mathrm{cm}^{2}\right)$. The leaves were then separated into categories according to their length: very small $<4.0 \mathrm{~cm}$; small $4.1-5.9 \mathrm{~cm}$; medium $6.0-8.9 \mathrm{~cm}$; large $9.0-$ $10.9 \mathrm{~cm}$; and very large $>11.0 \mathrm{~cm}$.

The experiment was set up as one factorial random block design, with 4 blocks (chambers) and 8 replications per treatment. The different levels of UV$-\mathrm{B}_{\mathrm{BE}}$ radiation: $0 ; 4 ; 6$ or $8 \mathrm{~kJ} \times \mathrm{m}^{-2} \cdot \mathrm{d}^{-1}$, were considered as a factor. The data were analyzed by the GLM procedure using SAS ver. 9.2 software. The experiment was repeated. Non-significant differences were observed between experiments and the data from both sets were therefore pooled.

\section{RESULTS AND DISCUSSION}

After 3 months of growth under different levels of $\mathrm{UV}-\mathrm{B}_{\mathrm{BE}}$ radiation, all hoary alyssum plants were in the rosette phase. There was high variation in the number of leaves per plant, regardless of the UV- $\mathrm{B}_{\mathrm{BE}}$ treatment, in a range between 30 and 72 leaves per plant. The average number of leaves per plant treated with different levels of UV- $\mathrm{B}_{\mathrm{BE}}$ radiation was similar and not significantly influenced by this stress factor, although a slight decrease in the leaf number was noted for UV- $B_{\mathrm{BE}}$ treated plants, between 8-22\%, comparing to the control (Table 1). The leaf area and specific leaf weight (SLW) were unaffected by UV radiation and very similar among treatments. As for leaf length, lamina length was unaffected by UV- $\mathrm{B}_{\mathrm{BE}}$ treatment but, on the other hand, a visible and significant reduction of the stalk length in the presence of $U V-B_{B E}$ radiation was observed. With increasing doses of UV-B $B_{\mathrm{BE}}$ radiation, the stalk length decreased, with significantly shorter stalks in plants treated with the highest level of UV- $\mathrm{B}_{\mathrm{BE}}, 8 \mathrm{~kJ}$, by about $26 \%$, as compared to the control (Table 1).

Some leaf categories were recognizable based on the length of their leaves. The most frequent in hoary alyssum rosettes, regardless of UV-B treatment, were leaves of medium size; their share was in a range from $49-56 \%$ (Table 2). At the same time, some other relationships were noted, as with the increasing dose of UV- $\mathrm{B}_{\mathrm{BE}}$ treatment the share of large and very large leaves was visibly decreasing, but at the same time the share of small leaves was increasing. The highest percentage of large and very large leaves was noted in rosettes of control plants (22\% in total), whereas the share of large leaves in rosettes treated with $8 \mathrm{~kJ}$ of UV- $B_{\mathrm{BE}}$ was just $5 \%$ without the presence of leaves of the very large category. The highest share of small leaves was noted for plants growing under $8 \mathrm{~kJ}$ of UV-B $B_{\mathrm{BE}}$ (Table 2). The results obtained suggest that hoary alyssum plants exposed to increased levels of UV-B ${ }_{\mathrm{BE}}$ radiation occupy less area. Hectors et al. (2007) confirm that rosettes of Arabidopsis thaliana plants exposed to UV-B treatment are smaller in diameter. This may serve as a kind of protection against $\mathrm{UV}-\mathrm{B}_{\mathrm{BE}}$ radiation, as leaf laminas in the rosette are not exposed so much to the radiation and cover one another. On the other hand, more compacted plants may be less competitive, and species growing more intensively in the first stages of development may lead to their shadowing (B arnes et al. 1990; B la ck, 1958).

The dry weight of Berteroa incana shoots was not significantly affected by any of the UV- $\mathrm{B}_{\mathrm{BE}}$ radiation levels, although a trend could be noticed, as with increasing doses of $\mathrm{UV}-\mathrm{B}_{\mathrm{BE}}$ radiation the shoot dry weight decreased, in comparison with the control, by about $6 \%$ and $18 \%$ for doses of 6 or $8 \mathrm{~kJ}$, respectively (Fig. 1). The root system was much more sensitive to $U V-B_{B E}$ radiation, as the root biomass was 
significantly affected even by the lowest UV-B $\mathrm{B}_{\mathrm{BE}}$ level of $4 \mathrm{~kJ}$. Compared to the control, the root biomass decreased by about 37\%, $17 \%$ and $30 \%$ for doses of 4, 6 or $8 \mathrm{~kJ}$, respectively (Fig. 2). Also the shoot/root biomass ratio decreased in $\mathrm{UV}-\mathrm{B}_{\mathrm{BE}}$ treated plants. For control plants, this ratio was 1:0.6, whereas for UV$-\mathrm{B}_{\mathrm{BE}}$ treated plants it was as follows: 1:0.4; 1:0.5 and $1: 0.5$, for plants growing in the presence of 4,6 or 8 $\mathrm{kJ}$ of UV-B $\mathrm{B}_{\mathrm{BE}}$, respectively. Vu et al. (1981) noticed a reduction of both shoot and root biomass of soybeans after treating them with an enhanced level of UV-B radiation. The reduced root biomass in plants exposed to increased UV- $\mathrm{B}_{\mathrm{BE}}$ amounts seems to be a limitation, although not reflected in the aboveground biomass accumulation up to the rosette phase. In the later generative phases, however, plant development may be slowed down, as a result of lowered root system efficiency, affecting the amount of fruits and seeds produced.

The relative chlorophyll content (SPAD) in the hoary alyssum leaves showed a high variation both between UV- $B_{\mathrm{BE}}$ doses and between plants within each dose of radiation, which resulted in non-significant differences (Fig. 3). This is consistent with the findings of Tosserams and Rozema (1995), according to which there are no effects of enhanced UV-B radiation on chlorophyll content and accumulation of UV absorbing pigments.

In summary, hoary alyssum (Berteroa inca$n a \mathrm{~L}$.) plants up to the rosette stage show low susceptibility to enhanced UV- $B_{\mathrm{BE}}$ treatment. A number of traits, namely leaf number, lamina length, leaf length and specific leaf weight in rosettes of hoary alyssum, are not affected by UV-B $\mathrm{B}_{\mathrm{BE}}$ treatment up to $8 \mathrm{~kJ}$ dose. At the same time, however, increasing doses of UV$-\mathrm{B}_{\mathrm{BE}}$ treatment cause a shortening of leaf stalks as well as a decrease in the share of large and very large leaves in the rosette. Also, a reduction of hoary alyssum root biomass in the presence of UV-B is noted. It is concluded that negative changes observed in the rosette phase may result in more adverse effects in the later generative phase of hoary alyssum development.

Table 1.

Morphological features of Berteroa incana (L.) after 3 months of growth under different levels of UV-B radiation (mean \pm SE)

\begin{tabular}{|c|c|c|c|c|c|}
\hline \multirow{2}{*}{ Trait } & \multicolumn{4}{|c|}{ UV-B ${ }_{\mathrm{BE}}$ level $\left(\mathrm{kJ} \times \mathrm{m}^{-2} \times \mathrm{d}^{-1}\right)$} & \multirow{2}{*}{$\mathrm{P}$} \\
\hline & $0 \mathrm{~kJ}$ & $4 \mathrm{~kJ}$ & $6 \mathrm{~kJ}$ & $8 \mathrm{~kJ}$ & \\
\hline Leaf number & $59.7(3.96)$ & $46.6(3.96)$ & $54.9(3.96)$ & $50.7(3.96)$ & 0.1 \\
\hline Lamina length $(\mathrm{cm})$ & $5.1(0.23)$ & $5.1(0.23)$ & $4.9(0.23)$ & $4.9(0.23)$ & 0.8 \\
\hline Stalk length $(\mathrm{cm})$ & $2.3(0.09)$ & $2.0(0.09)$ & $1.9(0.09)$ & $1.7(0.09)$ & 0.01 \\
\hline Leaf length (cm) & $7.5(0.32)$ & $7.1(0.31)$ & $6.7(0.32)$ & $6.6(0.30)$ & 0.4 \\
\hline Leaf area $\left(\mathrm{cm}^{2}\right)$ & $7.3(0.55)$ & $7.6(0.55)$ & $6.2(0.55)$ & $7.1(0.55)$ & 0.4 \\
\hline SLW* & $0.006(0.0007)$ & $0.006(0.0008)$ & $0.006(0.0007)$ & $0.006(0.0008)$ & 0.2 \\
\hline
\end{tabular}

* SLW - Specific Leaf Weight

Table 2

The percentage share of Berteroa incana (L.) leaves in different size categories after 3 months of growth under different levels of UV-B radiation

\begin{tabular}{|c|c|c|c|c|}
\hline \multirow{2}{*}{ Leaf category } & \multicolumn{4}{|c|}{ UV-B ${ }_{\mathrm{BE}}$ level $\left(\mathrm{kJ} \times \mathrm{m}^{-2} \times \mathrm{d}^{-1}\right)$} \\
\hline & $0 \mathrm{~kJ}$ & $4 \mathrm{~kJ}$ & $6 \mathrm{~kJ}$ & $8 \mathrm{~kJ}$ \\
\hline Very small & --- & 1 & --- & --- \\
\hline Small & 23 & 27 & 37 & 39 \\
\hline Medium & 55 & 56 & 50 & 56 \\
\hline Large & 18 & 14 & 12 & 5 \\
\hline Very large & 4 & 2 & 1 & --- \\
\hline Sum & 100 & 100 & 100 & 100 \\
\hline
\end{tabular}




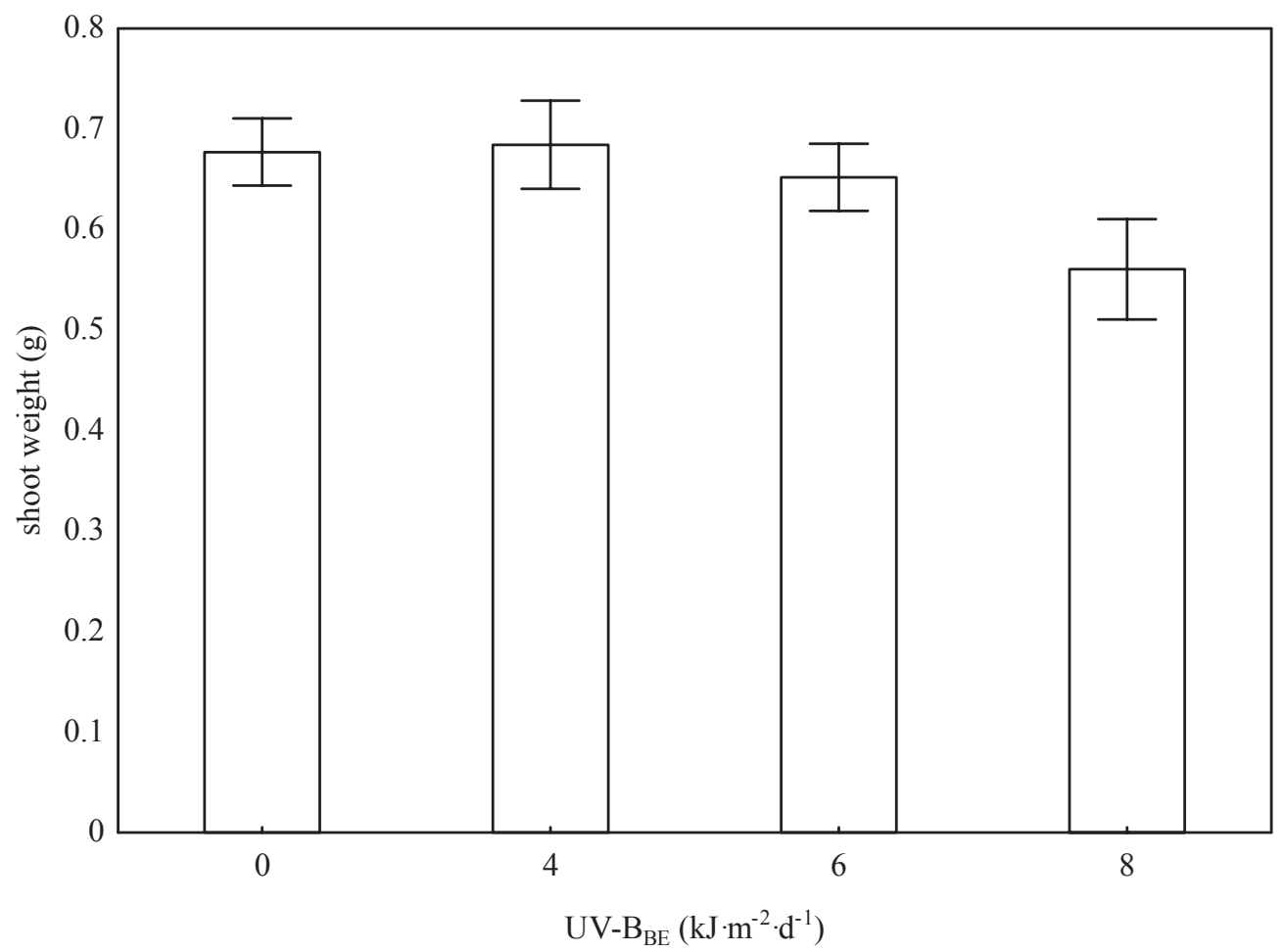

Fig. 1. Hoary alyssum shoot biomass (g) after treating with different levels of $\mathrm{UV}-\mathrm{B}_{\mathrm{BE}}$ radiation (mean $\pm \mathrm{SE} ; \mathrm{P}=0.4$ ).

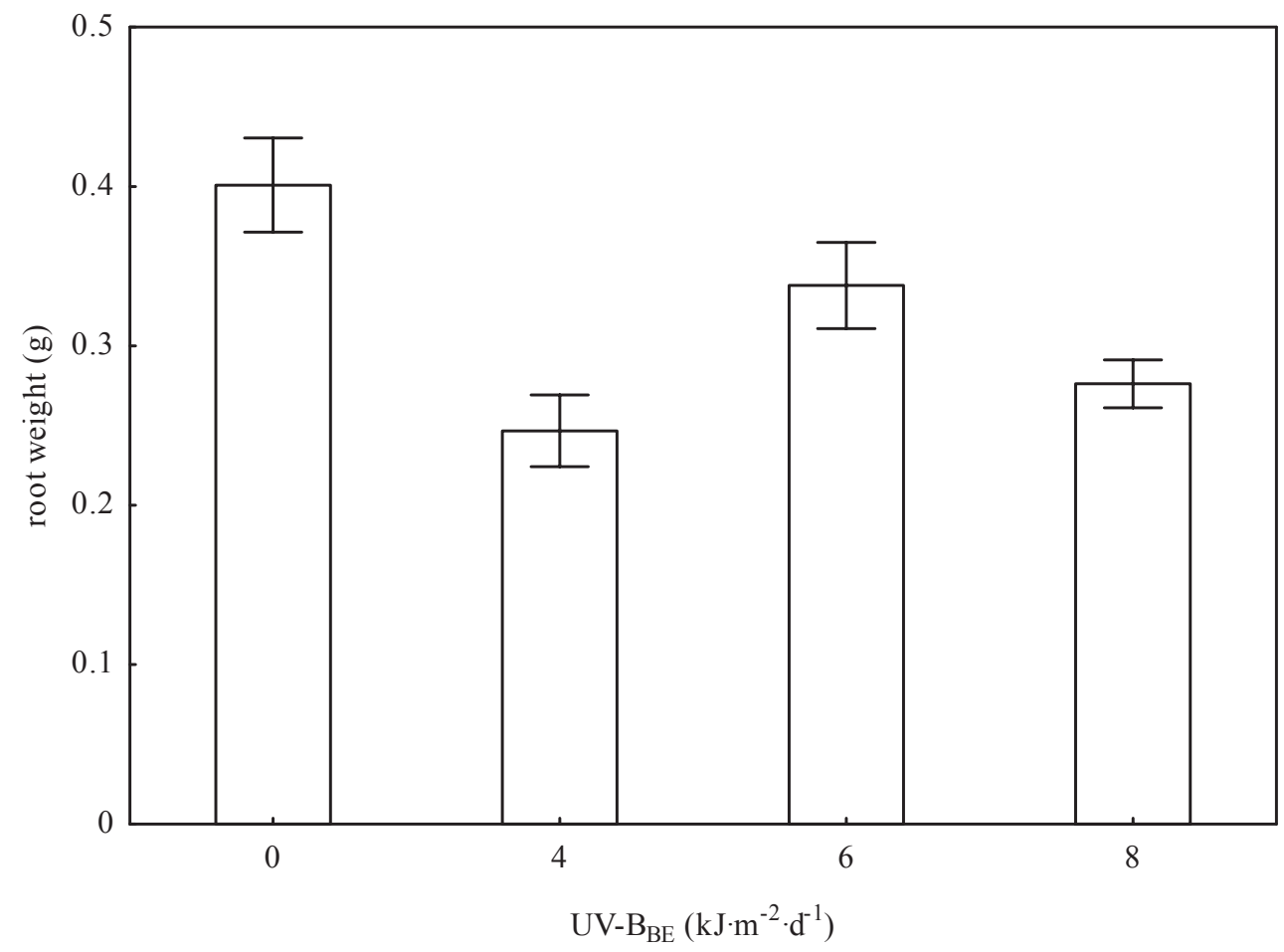

Fig. 2. Hoary alyssum root weight after treating with different levels of UV-B $B_{\mathrm{BE}}$ radiation (mean $\pm \mathrm{SE} ; \mathrm{P}=0.004$ ). 


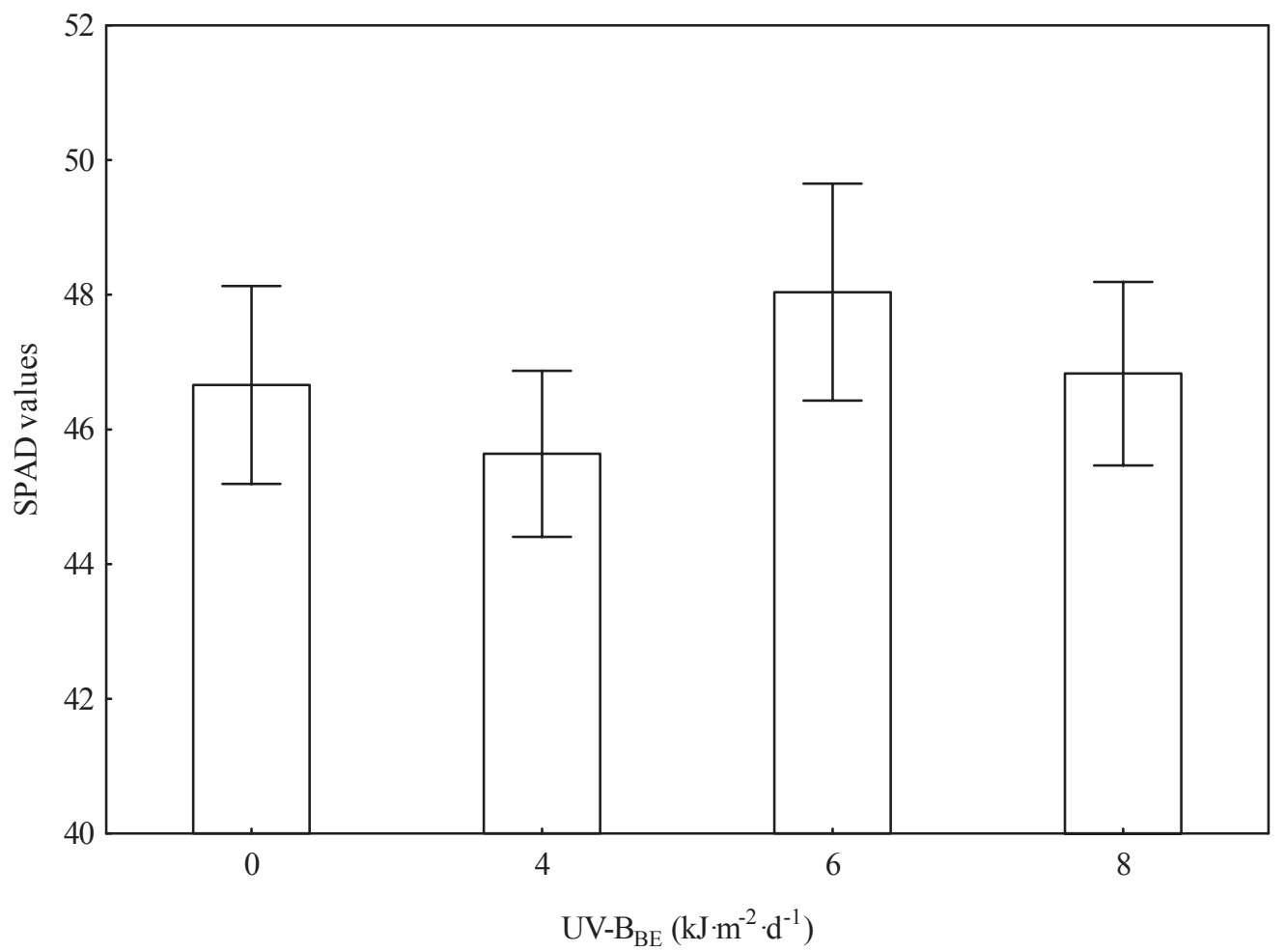

Fig. 3. Influence of different $U V-B_{\mathrm{BE}}$ levels on the relative chlorophyll content in hoary alyssum leaves (mean $\pm \mathrm{SE}$; $\left.\mathrm{P}=0.6\right)$.

\section{Acknowledgements}

The authors thank the Natural Science and Engineering Research Council of Canada (NSERC) for financial support.

\section{REFERENCES}

Barnes P.W., Flint S.D., Caldwell M.M., 1990. Morphological responses of crop and weed species of different growth forms to ultraviolet-B radiation. Amer. J. Bot. 77: 1354-1360.

Barnes P.W., Jordan P.W., Flint W.G., Caldwell M.M., 1988. Competition, morphology and canopy structure in wheat (Triticum aestivum L.) and wild oat (Avena fatua L.) exposed to enhanced ultraviolet-B radiation. Funct. Ecol. 2: 391-330.

B lack J.N., 1958. Competition between plants of different initial seed sizes in swards of subterranean clover (Trifolium subterraneum L.) with particular reference to leaf area and the light microclimate. Austral. J. Agric. Res. 9: 299-318.

Caldwe11 M.M., 1971. Solar UV irradiation and the growth and development of higher plants. [In:] Photophysiology A.C. Giese (ed.), Academic Press, New York.

Frohnmeyer H., Staiger D., 2003. Ultraviolet-B radiation-mediated responses in plants. Balancing damage and protection. Plant Physiol. 133: 1420-1428.

Furness N., Upadhyaya M.K., Ormrod D.P., 1999. Seedling growth and leaf surface morphological responses of three rangeland weeds to ultraviolet-B radiation. Weed Sci. 47: 427-434.

Gayton D., 2004. Native and non-native grass species in grazed grasslands of British Columbia's southern interior. BC J. Ecosyst. Manag. 5: 51-59.

Hectors K., Prinsen E., De Coen W., Jansen M.A.K., Guisez Y., 2007. Arabidopsis thaliana plants acclimated to low dose rates of ultraviolet $\mathrm{B}$ radiation show specific changes in morphology and gene expression in the absence of stress symptoms. New Phytol. 175: 255-270. doi: 10.1111/j.14698137.2007.02092.x

Kutyna I., Nieczkowska M., 2009. Ruderal communities occurring in the area of the former University of Agriculture in Szczecin situated in Słowackiego and Papieza Pawła VI streets (in Polish). Folia Pomer. Univer. Technol. Stetinen. 271: 55-74.

Madani H., Stopps G., Upadhyaya M.K., 2010. Seed germination ecophysiology of hoary alyssum (Berteroa incana L.) in different temperature, dry heat and anaerobiosis conditions. Plant Ecophysiol. 2: 121-126.

Parkinson H., Mangold J., Jacobs J., 2010. Biology, ecology and management of hoary alyssum (Berteroa incana L.). EB0194 March 2010, Montana State University Extension.

Reichman O.J., 1988. Comparison of the effects of crowding and pocket gopher disturbance on mortality, growth and seed production of Berteroa incana. The Amer. Midland Natural. 120: 58-69. 
Skrzyczyńska J., Ługowska M., Pawlonka Z., 2010. Floristic biodiversity of the flood and meadow terraces of the Eastern part of the Middle Vistula Valley (in Polish). Fragm. Agronom. 27: 127-134.

Tosserams M,, Rozema J., 1995. Effects of ultraviolet-B radiation (UV-B) on growth and physiology of the dune grassland species Calamagrostis epigeios. Environ. Pollut. 89: 209-214. doi: 10.1016/02697491(94)00062-I

Vu C.V., Allen L.H., Garrard L.A., 1981. Effects of supplemental UV-B radiation on growth and leaf photosynthetic reactions of soybean (Glycine max). Physiol. Plant. 52: 353-362. doi: 10.1111/j.13993054.1981.tb06054.x

Warwick S.I., Francis A., 2006. The biology of invasive alien plants in Canada. 6. Berteroa incana (L.) DC. Can. J. Plant Sci. 86: 297-1309.

\section{Reakcja pyleńca pospolitego (Berteroa incana L.) na promieniowanie $\mathbf{U V}-\mathrm{B}$}

\author{
Streszczenie
}

Celem pracy było zbadanie reakcji pyleńca pospolitego (Berteroa incana L.), do fazy rozety liściowej, na promieniowanie UV-B. Doświadczenie przeprowadzono w warunkach szklarniowych, w komorach wyposażonych w lampy emitujące biologicznie czynne promieniowanie UV-B w stężeniu: 0 (kontrola), 4, 6 i $8 \mathrm{~kJ}$. W wyniku przeprowadzonych badań stwierdzono, że zastosowane promieniowanie nie wpływało na takie cechy roślin, jak: liczba liści, długość blaszki liściowej, powierzchnia liści, specyficzna masa liści (SLW) oraz względna zawartość chlorofilu (w jednostkach SPAD) i masa części nadziemnych. Natomiast zaobserwowano istotną redukcję w udziale dużych liści, w długości ogonków liściowych i biomasie korzeni u roślin eksponowanych na najwyższe, $8 \mathrm{~kJ}$ UV-B ${ }_{\mathrm{BE}}$, promieniowanie UV-B. 